\title{
ROOT INJURY TO CONIFERS IN CANADA BY SPECIES OF HYLOBIUS AND HYPOMOLYX (COLEOPTERA:CURCULIONIDAE) ${ }^{1}$
}

\author{
BY G. L. WARREN ${ }^{2}$
}

G. L. Warren served in the R.C.A.F. during World War II and on completion of hositilities entered the Faculty of Agriculture at the University of Manitoba, graduating in 1950. Completed the degree of Master of Science from McGill University in 1953, majoring in Entomology. He has been employed by the Division of Forest Biology, Canada Department of Agriculture, as a research officer in Winnipeg since 1950.

\section{INTRODUCTION}

Because of their insidious nature, insects attacking the roots of forest trees have been frequently overlooked by the forester and research worker. It is only in the past decade that their potential destructiveness has been recognized in Canada. Some conifer plantations have recently been virtually destroyed by larvae feeding on the root system and girdling the root collar of practically every tree. Natural stands, however, seldom exhibit extensive mortality from root-boring insects but the combined effect of larval feeding and the occurrence of disease organisms associated with the feeding wounds predisposes trees to early maturity.

The insects discussed in this paper belong to closely related genera of weevils, Hylobius and Hypomolyx, of the family Curculionidae. The genus Hylobius contains two species that are considered economically important in North America. These are the pales weevil, Hylobius pales (Hbst.) and the pine root-collar weevil, Hylobius radicis (Buchanan). Only the latter is a primary invader and is the species intended when the generic name Hylobius is used in the discussion that follows. The genus Hypomolyx, hitherto, has been represented by one known species, Hypomolyx piceus (DeGeer), in North America (1). It has occasionally been referred to in the literature as the "large spruce weevil", but this common name has not been approved by the American Association of Economic Entomologists. In 1952 the writer discovered that the species contained two "forms" that are easily separated by wing characters. The status of these "forms" is being investigated by Dr. Stephen L. Wood, Division of Entomology, Ottawa, Ontario, and they will probably be given specific rank. Until their status has been definitely established, it is adequate to refer to them collectively under the generic name Hypomolyx.

Hylobius has been reported attacking Scots, Austrian, Corsican, lodgepole, Mugo, pitch, red, and eastern white pine, with the most severe infestations occurring on the first five species, $(2,3,4)$. This insect was discovered in the Lake Simcoe District near Angus, Ontario, in 1953. Other small outbreaks were discovered in 1955 near Sault Ste. Marie, Ontario, and southeastern Manitoba.

\footnotetext{
${ }^{2}$ Contribution No. 249, Forest Biology Division, Science Service, Department of Agriculture, Ottawa, Ontario, Canada.

Research Officer, Forest Biology Laboratory, Winnipeg, Manitoba.
} 
These infestations are relatively small in area but severe in intensity. Conversely, Hypomolyx is widely distributed and attacks more host species. Field observations and examination of material submitted from other Forest Biology Laboratories, has shown positively that this insect attacks Scots, jack, lodgepole, red, eastern and western white pine; black, white, and Norway spruce; and tamarack. Reports give evidence of attack on other conifers. Scots, jack, and lodgepole pine and white spruce seem to be most susceptible to attack. It is interesting to note that no similar damage has ever been reported on balsam fir. The examination of this tree species growing adjacent to heavily infested white spruce showed no evidence of attack by either of these root insects.

\section{Damage and Environmental Relationships}

These insects have similar life histories, spending part of two seasons as larvae and one or more years as adults $(4,6)$. The principal damage is caused by the larvae, which bore into the bark and cambial regions of the host tree at or below ground level. They often completely girdle the trunk at the root collar and the basal portions of the larger lateral roots. There are characteristic differences in the damage caused by these two species. Since mature Hylobius larvae are smaller than Hypomolyx larvae, their tunnels are necessarily smaller and less definitive. Also, the former tend to girdle the root collar more completely.

Hylobius attacks trees of all ages but appears to prefer those between 5 and 20 years of age. Hypomolyx prefers slightly larger trees but the highest mortality occurs in those under 40 years of age. Mature trees are frequently heavily attacked, and although some of the roots may die, tree mortality due to girdling is rare. It is these older trees that usually exhibit the association of insect damage with the entrance of disease organisms. Practically all the trees in susceptible natural stands will show some larval scars. Plantations are considered even more vulnerable.

Many factors appear to affect the prevalence of these insects in a stand. Among these are certain site factors. It has been found that the largest populations of Hypomolyx occur in moist to wet conditions (6). These conditions may be related to soil type, stand age and composition, nature of the humus layer and ground vegetation, and they are usually associated with the heavier, poorlydrained forest soils. However, certain local factors of stand composition and climate may produce moist conditions suitable to the requirements of these insects, even on sandy, well-drained soils. Such an instance was encountered in a Scots pine plantation at Valcartier, Quebec, during the summer of 1955 . The plantation was established on a sandy, well-drained soil but the ground cover consisted of a thick layer of the common hair cap moss. This moss maintained a high moisture content about the root collar of the host, providing conditions similar to the wet sites usually associated with heavier soils. All the trees were severely infested. Although past mortality was limited to a few trees, severe root damage indicated that heavy mortality can be expected.

In contrast to the requirements of Hypomolyx, Hylobius attacks only trees growing in sandy, well-drained soils (4). Furthermore, infestations of this species appear to be more sporadic than those of Hypomolyx. A stand may 
be heavily infested while adjacent ones, growing under apparently similar conditions, may be free from attack. The reasons for the difference in degree of infestation between stands are not clear.

\section{ConTroL}

Very little experimental work has been conducted on the control of root insects in Canada, but the theme of this meeting dictates the need for some reference to this subject. By economic requirement, artificial control of these insects is limited to plantations or ornamental trees. Investigations indicate that forms of preventative control may be successful and practical. Only a few aspects of control are discussed and these are included under the headings chemical control, mechanical control, and control by management.

\section{Chemical Control}

No successful method for the chemical control of Hylobius weevils had been developed in North America prior to 1939 (4). Shaffner and McIntyre (4) state, "Since 1939 a number of chemicals have been tried by the Division of Forest Investigations, and although a few have given promising results, none gave complete control". Their best results were obtained with an emulsion containing $25 \%$ of ethylene dichloride, combined with either dinitro-o-cyclohexyl phenol $(100 \%)$, added at the rate of 0.5 ounce per gallon of emulsion, or $5 \%$ of dichloroethyl ether. Both treatments were used at the rate of one-half pint per tree, for trees under 4 inches in diameter at the base, and one pint for trees over 4 inches.

The first research on the chemical control of Hylobius in Canada, was initiated in Ontario in 1954. Results of these experiments are not completed but Dr. J. J. Fettes, Forest Biology Division, Ottawa, Ontario, reports (personal communication) that heavy applications of ethylene dichloride (up to 50\%) gave $100 \%$ control for at least the current season, and benzine hexachloride appears to act as a preventative to reinfestation. These insecticides are applied directly to the root-collar area of each tree. The method of application of insecticides to plantation stock may be very important. It has been shown (5) that the indiscriminate use of some insecticides has severe inhibitory effects on the development of conifer seedlings.

\section{Mechanical Control}

This method of control usually implies the removal and destruction of infested stock. Unfortunately, this approach offers little aid since stands are heavily infested by the time external symptoms become evident. Therefore, the entire stand or plantation would have to be destroyed and the ground left fallow and replanted with a less susceptible tree species.

Experience with Hypomolyx indicates that it may be controlled successfully by removing the humus from the vicinity of the root collar and basal portions of the major roots. Since these insects have a high moisture requirement, the humus layer is necessary to protect their habitat. The possibility of controlling Hylobius by this method seems remote since it occurs in the absence of a well-developed humus layer. 


\section{Control by Management}

Management practices offer the most practical approach to the control of these root insects. The selection of site and tree species appears most important when planning future plantation and reforestation programs.

On light soils, where Hylobius may occur, it is inadvisable to plant exotic pines or native red and jack pines near the more susceptible exotic species. It is obvious that exotic pines should not be used to refill present plantations of native species. Several plantations of exotic species in Manitoba were refilled with native stock that is now being infested.

It his been indicated that very moist or wet sites are preferred by Hypomolyx. The most susceptible host species, pine and white spruce, should not be planted on these sites. Possibly better use could be made of the less susceptible black spruce and tamarack.

Another feature of management must be considered where reforestation of logged, burned-over, or windthrown areas is anticipated. Unless immediate sanitation is practiced, these areas become littered with rotted logs which increase the incidence of Hypomolyx attack (6). Therefore, strict sanitation is a prerequisite to planting susceptible conifers in disturbed areas.

\section{REFERENCES}

1. BLATCHLEY, W. S. and C. W. LENG. 1916. Rhynchophora or weevils of Northeastern America. The Nature Publishing Co. Indianapolis, Ind. p. 186.

2. BROWN, ROBERT T. and EUGENE P. YOUNG. 1955. Insect attacks on native and plantation pines in central Wisconsin. Ecology 36(3):522-523.

3. PRENTICE, R. M. 1955. Pine root-collar weevil in Manitoba. Can. Dept. Agr. For. Biol. Div. Bi-Monthly Prog. Rpt. 11 (4):1-2.

4. SHAFFNER, J. V., JR. and H. L. McINTYRE. 1944. The pine-root collar weevil. Jour. Forestry 42:269-275.

5. VOIGT, G. K. 1955. The effect of applied fungicides, herbicides and insecticides on the content of nutrient elements in tissue of coniferous seedlings. Proc. Soil Sci. Soc. Amer. $19(2): 237-239$.

6. WARREN, G. L. The effect of some site factors on the abundance of Hypomolyx piceus (DeG.) (Coleoptera:Curculionidae). Ecology. In press. 